\begin{tabular}{cccccccc}
$\mathbf{R}$ & $\mathbf{E}$ & $\mathbf{C}$ & $\mathbf{E}$ & $\mathbf{N}$ & $\mathbf{Z}$ & $\mathbf{J}$ & $\mathbf{E}$ \\
\hline & & $\begin{array}{l}\text { ROCZNIKI TEOLLGICZNE } \\
\text { Tom LXVI, zeszyt } 4-2019\end{array}$ & & \\
& & &
\end{tabular}

KS. ANDRZEJ GÓRSKI

Instytut Historii Kościoła i Patrologii KUL (doktorant)

e-mail: gorski80@wp.pl

\title{
TESTAMENTY CHŁOPÓW POLSKICH
}

Janusz ŁOSOWSKI, Testamenty chłopów polskich od drugiej połowy XVI do XVIII wieku,Wydawnictwo UMCS, Lublin 2016, ss. 520; ISBN 978-83-7784-791-6

DOI: http://dx.doi.org/10.18290/rt.2019.66.4-11

Poznawanie dziejów naszych przodków, a w szczególności historii rodzinnych, sytuacji majątkowych oraz miejsc, w których nie tylko przyszli oni na świat, lecz również oczekiwali odejścia z niego, od zawsze wywołuje duże zainteresowanie wśród wielu różnych badaczy. Niezastąpioną pomocą w tej kwestii są testamenty, jakie były spisywane nie tylko przez zamożnych tego świata, lecz również przez skromnych i prostych ludzi.

Ten akt ostatniej woli, człowieka przygotowującego się do śmierci, stanowił często dokument materialnego rozrachunku z życiem oraz szczególny akt wiary, który pozwalał uwolnić duszę zmarłej osoby od wyrządzonych niegdyś krzywd. Jak wierzono, taka dusza obdarzona Boskim miłosierdziem - mogła otrzymać życie wieczne, dlatego w testamentach staropolskich, może nie we wszystkich, ale jakże często w pierwszym zdaniu pojawia się odwołanie do Imienia Bożego, czy też Trójcy Świętej. Następnie zapisanie „będąc chorym na ciele, jednak zdrowym na umyśle" w tej lub innej formie miało udowodnić poczytalność testatora. Ważne było również ukazanie swojego stanu majątkowego, jakim jeszcze dysponował i decyzje, jakie podejmował w związku z jego podziałem. Prawnym zabezpieczeniem owych dokumentów miało być złożenie przez testatora podpisu lub stawianego krzyża w obecności świadków, gdy był osobą niepiśmienną, zaś zapisanie testamentu w aktach grodzkich miało na celu udowodnienie prawomocności tego dokumentu. Istotne również było wyznaczenie w testamencie odpowiednich osób, które miały za zadanie wypełnić wolę testatora.

Janusz Łosowski, autor omawianego dzieła, po ukończeniu studiów historycznych w Uniwersytecie Marii Curie-Skłodowskiej pracował w Archiwum Państwowym w Przemyślu, następnie w Archiwum Państwowym w Lublinie na stanowisku starszego archiwisty i kustosza tego Archiwum. W 1992 roku obronił pracę doktorską, a w 2005 roku pracę habilitacyjną. Przez kolejne trzy lata pełnił funkcję zastępcy dyrektora Instytutu Historii 
UMCS, zaś w 2009 roku uzyskał tytuł profesora nadzwyczajnego UMCS. W latach 20082010 brał udział w pracach nad polskim podręcznikiem dyplomatyki, a w 2011 roku otrzymał Indywidualny grant Ministerstwa Nauki i Szkolnictwa Wyższego, zrealizowany w latach 2012-2015, zakończony publikacją dzieła Testamenty chłopów polskich od drugiej połowy XVI do XVIII wieku. W związku z tą pracą przeprowadził kwerendę biblioteczną i archiwalną w Berlinie, Kijowie oraz Mińsku. W 2014 roku uzyskał tytuł profesora, a od 1 października 2016 roku stanowisko profesora zwyczajnego.

Wykształcenie, jak również zapał w pracy badawczej pozwoliły Januszowi Łosowskiemu na przeprowadzenie kwerendy i opublikowanie monumentalnej krytycznej edycji 326 testamentów chłopów z epoki staropolskiej. Zostały one odnalezione w archiwach i bibliotekach znajdujących się w Polsce, Ukrainie i Białorusi. Omawiana publikacja została poprzedzona, na pierwszych 10 stronach, wykazem skrótów, jakie autor zastosował w swoim dziele i 48 stronach - wstępem wydawniczym umieszczonym w dziesięciu podrozdziałach, w którym zawarł cel edycji i jego zakres chronologiczny, opisał definicję testamentu, okoliczności jego powstawania oraz jego autorów, którzy zazwyczaj byli niepiśmienni, a w ich imieniu czynili to bądź pisarze gromadzcy lub nauczyciele miejscowych szkół, bądź bracia zakonni z pobliskich klasztorów. Rodzaje i formy testamentów jak również części składowe i ich formuły zajmują kolejne karty wstępu. W nich można wyróżnić trzy zasadnicze części znane z dokumentów średniowiecznych, takie jak: protokół, kontekst i eschatokół. Na kolejnych kartach wstępu autor przedstawił w głównej mierze dwie grupy formularzy testamentów, z których korzystano podczas ich spisywania. Jedne bardzo zwięzłe, zaś drugą grupę stanowią formularze obszerne i bogate w treści. Religijne elementy testamentów, a także ich różnorodność stanowi świadectwo wielkiego znaczenia wiary w Boga w życiu ówczesnych chłopów. Natomiast problem powtarzalności formuł dowodzi, że przy spisywaniu omawianych testamentów chłopskich wzorem były już wcześniej sporządzone takie dokumenty. Funkcje testamentów stanowi kolejny paragraf wstępu omawianego dzieła. Głównym jego zadaniem miało być wprowadzenie nowego porządku w stanie posiadania, który miał obowiązywać po śmierci testatora, choć nie zawsze z jego wolą zgadzała się najbliższa rodzina. Również o takich przypadkach możemy przeczytać w niejednym przytoczonym testamencie. Na kolejnych stronach autor omawia wartość źródłową testamentów, które dostarczają ciekawych informacji, które nie tylko ułatwiają prowadzenie różnorodnych badań, ale także pozwalają zapoznać się z codziennym życiem zwykłego chłopa. W przedostatnim podrozdziale autor omawia pochodzenie, chronologię i obecne miejsca przechowywania testamentów w głównej mierze w postaci wpisów do akt gromadzkich. W tej formie zachowały się one w większym stopniu niż dokumenty znajdujące się u indywidualnych gospodarzy, gdyż były znacznie lepiej od nich chronione. Zasady edycji kończą wstęp omawianej publikacji.

Autor tego dzieła, Janusz Łosowski, przygotowując to wydanie skorzystał z instrukcji wydawniczej dla źródeł historycznych od XVI do XIX wieku, co pozwoliło mu na osiągnięcie bardzo dobrego rezultatu w postaci opracowania testamentów chłopów polskich z okresu staropolskiego.

W tym miejscu nie sposób wymienić wszystkie obszary badawcze, jakich podjął się autor, opracowując materiały źródłowe, jakie udało mu się odnaleźć w różnych archiwach. To monumentalne dzieło stanowi również niecodzienne źródło, niejako kopalnię wiedzy na temat sytuacji ekonomicznej chłopów, członków ich rodzin, inwentarza martwego i żywego 
oraz posiadanej ziemi, do której niejednokrotnie podchodzono z wielką czcią i pietyzmem. Zastosowane przez autora pracy zasady edytorskie i konsekwentne ich realizowanie, jak np.: podział każdego tekstu na akapity, czy pominięcie niekiedy nieistotnych dla treści źródeł nagłówków pozwoliły pozytywnie wpłynąć na przejrzystość pracy. Dużą pomocą w dobrej orientacji, po zamieszczonych dokumentach, są umieszczone indeksy: geograficzny, rzeczowy i osobowy. Indeks geograficzny pozwala szybko odszukać interesującą nas miejscowość, a także niekiedy prześledzić jej zmiany terytorialne. W indeksie rzeczowym często odnajdujemy nazwy własne nie tylko przedmiotów, które obecnie już nie są używane, jak np: berda, rzezaczka czy tunka, lecz także przeróżnych nazw tkanin: rańtuch, czamlot czy haras. Natomiast w indeksie osobowym odnajdujemy z imienia i nazwiska testatorów, a także kasztelanów, starostów, dzierżawców gruntów czy nawet księży diecezjalnych i ojców zakonnych.

Bogaty zbiór informacji, zawarty w omawianym dziele, to dobre źródło nie tylko dla osób z wykształceniem historycznym, lecz również dla amatorów, którzy mają potrzebę głębszego poznania klimatu życia na wsi w okresie staropolskim, jednocześnie obszerny i charakterystyczny materiał, zgromadzony we wspomnianej publikacji, może a zarazem powinien być ciągle uzupełniany w miarę odkrywania nowych źródeł związanych z tematem omawianej pracy.

GRZEGORZ KAMIL SZCZECINA

Instytut Historii Kościoła i Patrologii KUL(doktorant)

e-mail: grzesszczecina@interia.pl

\section{POLSCY ŚWIĘCI MĘCZENNICY}

Stefan BUDZYŃSKI, Stanisław URBAŃSKI, Anna ZIÓŁKOWsKA, Polscy święci męczennicy. Znani i nieznani, Oficyna Wydawniczo-Poligraficzna ADAM, Warszawa 2015, ss. 296.

DOI: http://dx.doi.org/10.18290/rt.2019.66.4-12

Od początku istnienia Kościoła pojęcie męczeństwa jest nierozerwalnie złączone z chrześcijaństwem i wymiarem religijnym. Począwszy od pierwotnej wspólnoty chrześcijan, przez kolejne wieki, wielu doświadczało prześladowań za wiarę i postawę godną świadka Jezusa Chrystusa. Tych, którzy oddali swoje życie, można liczyć w tysiącach. Dlatego też w tradycji pierwotnego Kościoła słowo martyr, oznaczające świadka, zaczęto odnosić do tych, którzy przelaną krwią zaświadczyli o swej wierności Zbawicielowi. Stali się tym sa- 